\title{
Pembelajaran Guru PAUD Jabodetabek: Studi Terhadap Faktor-Faktor yang Mempengaruhi Pembelajaran Guru PAUD JABODETABEK Tahun 2014/2015 ${ }^{1}$
}

\author{
${ }^{1}$ Fidesrinur, ${ }^{2}$ Nurfadilah, ${ }^{3}$ Nila Fitria \\ ${ }^{1,2,3}$ Program Studi Pendidikan Anak Usia Dini, Fakultas Psikologi dan Pendidikan \\ Universitas Al Azhar Indonesia, Jl.Sisingamangaraja, Jakarta 12110 \\ Penulis untuk Korespondensi/E-mail: fideza@uai.ac.id
}

\begin{abstract}
Abstrak - Perkembangan pendidikan anak usia dini berkembang dengan pesat. Hal tersebut tentunya tidak lepas dari konteks pembelajaran yang dilakukan di lembaga PAUD. Konteks pembelajaran dipengaruhi oleh berbagai factor, (1)sarana prasarana,(2) tenaga pendidik, sekolah, (3) tenaga kependidikan, dan factor psikologis lainnya. Tujuan dari penelitian ini adalah untuk mengetahui factor-faktor yang mempengaruhi pembelajaran guru PAUD Jabodetabek. Penelitian ini bersifat deskriptif analitik, yaitu data dideskripsikan dengan menggunakan statistik deskriptif, dan dimaknai secara mendalam berdasarkan perspektif emik yaitu penyajian data secara alamiah tanpa melakukan suatu manipulasi atau perlakuan terhadap subjek yang diteliti serta diperkuat melalui triangulasi data melalui observasi dan wawancara pengurus dan pendidik PAUD, orang tua, dan masyarakat sekitar sekolah. Terdapat 21 lembaga PAUD dalam penelitian ini. Berdasarkan hasil penelitian dapat disimpulkan : pertama, terdapat $85 \%$ pembelajaran dilakukan dengan konteks pembelajaran klasikal, kedua, terdapat beberapa factor yang mempengaruhi pembelajaran guru PAUD, yaitu: (1) luas lahan yang tidak memenuhi standar (2) kompetensi pendidik yang kurang mengeksplore potensi anak didik (3) biaya pendidikan yang bersaing dengan lembaga PAUD lainnya dan (4) sarana prasarana yang sangat minim.
\end{abstract}

Kata Kunci: Penguasaan Pembelajran, Pendekatan Pembelajaran, Pendidikan Anak Usia Dini, Guru

Abstract - The development of early childhood education is growing rapidly. It certainly can not be separated from the context of learning conducted in PAUD institutions. The context of learning is influenced by various factors, (1) infrastructure, (2) educators, schools, (3) education personnel, and other psychological factors. The purpose of this study is to determine the factors that affect learning early childhood teachers Jabodetabek. This research is analytic descriptive, the data is described by using descriptive statistics, and interpreted in depth based on the perspective of emik is the presentation of data naturally without doing a manipulation or treatment of the subject under study and strengthened through triangulation of data through observation and interviews of PAUD administrators and educators, parents, and communities around the school. There are 21 PAUD institutions in this study. Based on the result of the research, it can be concluded that firstly, $85 \%$ of learning is done with the context of classical learning. Secondly, there are several factors influencing the learning of early childhood teachers: (1) the area of land that does not meet the standard (2) educative (3) educational costs that compete with other early childhood institutions and (4) infrastructure facilities are very minimal.

Keyword - Learning Mastery, Learning Approach, Early Childhood Education, Teacher

\footnotetext{
${ }^{1}$ Paper ini telah diseminarkan di seminar internasional " International Conference of Early Childhood Education 2015 (ICECE ) Universitas Padang pada tanggal 20-21 September 2015
} 


\section{PENDAHULUAN}

\section{Latar Belakang}

Ank usia dini adalah anak usia lahir sampai dengan 8 tahun. Pada usia tersebut pertumbuhan dan perkembangan manusia sangat kritis karena akan berpengaruh pada kehidupan manusia selanjutnya. Oleh karena itu, Pendidikan Anak Usia Dini (PAUD) memegang peranan penting dalam mengoptimalkan potensi yang dimiliki oleh anak dengan memberikan stimulasi di berbagai aspek perkembangan.

Pentingnya Pendidikan Anak Usia Dini telah banyak diteliti para ahli. Satu di antaranya adalah Lindsey (dalam Arce 2000:07), yang mengungkapkan bahwa perkembangan jaringan otak dan periode perkembangan kritis secara signifikan terjadi pada tahun-tahun usia dini, dan perkembangan tersebut sangat ditentukan oleh lingkungan dan pengasuhan. Pentingnya PAUD juga dikemukakan oleh Feldman (2002) bahwa masa balita merupakan masa emas yang tidak akan berulang karena merupakan masa paling penting dalam pembentukan dasar-dasar kepribadian, kemampuan berfikir, kecerdasan, keterampilan, dan kemampuan bersosialisasi. Kenyataan ini memperkuat keyakinan bahwa pendidikan dasar bagi anak seyogianya dimulai sedini mungkin, tidak hanya di usia pendidikan dasar 9 tahun dimana setelah sebagian besar kemungkinan pengembangan potensi anak mulai berkurang. Penelitian tentang otak menunjukkan sampai usia 4 tahun tingkat kapabilitas kecerdasan anak telah mencapai $50 \%$, pada usia 8 tahun mencapai $80 \%$, dan sisanya sekitar $20 \%$ diperoleh pada saat berusia 8 tahun ke atas. Artinya apabila pendidikan baru dilakukan pada usia 7 tahun atau sekolah dasar stimulasi lingkungan terhadap fungsi otak yang telah berkembang $80 \%$ tersebut terlambat dalam pengembangannya. Otak yang kurang difungsikan tidak hanya membuat anak kurang cerdas tetapi dapat mengurangi optimalisasi potensi otak yang seharusnya dimiliki oleh anak.

Optimalisasi potensi anak sebagaimana dikemukakan di atas sangat tergantung pada lingkungan yang membentuknya mulai dari keluarga, masyarakat dan utamanya sekolah yang dipersiapkan khusus untuk pendidikan. Yussen \& Santrock (1980:373) mengatakan bahwa kemampuan sosialisasi anak sangat terkait dengan orang-orang di sekeliling anak yang disebut agen sosial, yaitu setiap orang yang berhubungan dengan seorang anak misalnya ayah dan ibunya, pengasuh, teman sebaya, guru dan keluarga lainnya dan orang tersebut mempengaruhi cara anak berperilaku. Dalam kaitan itu pula Feeney (2006:55) mengemukakan bahwa sebagian besar nilainilai dan pelaksananan program pendidikan anak tumbuh dari nilai anak dalam suatu masyarakat yang diadopsi secara turun temurun, di antaranya juga dipengaruhi oleh pemimpin agama, pembaharu masyarakat, dan pendidik di masa sebelumnya.

Para ahli pendidikan di Indonesia meyakini bahwa penyebab rendahnya kualitas manusia Indonesia disebabkan oleh orientasi pembelajaran yang bersifat kognitif dan mengabaikan afektif dan psikomotorik. Pengabaian terhadap pengembangan sikap dan perilaku serta keterampilan ini terlihat pada orientasi pembelajaran anak usia dini pada menulis membaca dan berhitung (Calistung). Padahal calistung dikembangkan melalui pembelajaran yang bersifat abstrak sementara pembelajaran PAUD semestinya bersifat kongkrit sehingga anak memperoleh pengalaman langsung dan disesuaikan dengan tingkat pertumbuhan dan perkembangan anak.

Pada dasarnya upaya untuk memperkenalkan belajar melalui bermain sudah sering disosialisasikan baik dalam bentuk seminar maupun kegiatan diklat berjenjang. Bahkan belajar melalui bermain merupakan salah satu materi ajar yang menjadi bagian dari Diklat berjenjang tersebut, dan salah satu dasar dalam pengembangan kurikulum.

Pendekatan pembelajaran tidak mungkin hanya pada perbaikan paradigma guru tentang belajar melalui bermain tetapi terkait kebutuhan orang tua dan tuntutan lulusan PAUD saat memasuki SD. Pada saat ini kursus untuk anak usia dini guna meningkatkan kemampuan calistung menjamur di seluruh pelosok negeri guna memenuhi tuntutan pasar yang serba instan.

Permasalahan Pendidikan Anak Usia Dini dihadapkan pada permintaan pasar seperti permintaan orang tua, sekolah maupun masyarakat yang diawali dengan tuntutan masuk Sekolah Dasar. Permintaan sekolah Dasar misalnya, lulusan PAUD diharapkan 
sudah dapat membaca, menulis dan berhitung (Calistung). Merujuk kenyataan di atas diketahui bahwa pendekatan pembelajaran anak usia dini sangat bersifat sistemik. Pola pemikiran masyarakat yang serba instan dalam mendidik anak ini bertentangan dengan tujuan pendidikan anak usia dini yang bersifat holistik sehingga pendidikan bagi anak seutuhnya tidak dapat berkembang dengan baik. National Association for the Education of Young Children (NAEYC) atau Asosiasi Pendidikan Anak Usia Dini Nasional Amerika Serikat mengemukakan tiga dasar pemikiran dalam pengambilan keputusan profesional tentang anak usia dini: (1) pengetahuan tentang perkembangan anak dan pembelajaran, pengetahuan tentang umur dalam hubungannya dengan karakteristik manusia sebagai dasar untuk memprediksi tentang rentangan umur dan kegiatan yang akan dilakukan, materimateri, interaksi, pengalaman yang aman, sehat, menarik, dapat dikuasai dan juga manatang bagi anak; (2) pengetahuan tentang kekuatan, minat dan kebutuhan masing-masing individu anak dalam kelompok untuk penyesuaian diri dan merespon perbedaan yang ada; dan (3) pengetahuan tentang konteks sosial dan kultural dimana anak berada yang mendorong pengalaman pembelajaran yang bermakna, relevan dan penghargaan terhadap partisipasi anak dan keluarganya (Gestwicki, 2007:08).

Sehubungan dengan hal yang dikemukan di atas maka penelitian yang berjudul "PEMBELAJARAN GURU PAUD Jabodetabek: Studi terhadap Faktor-Faktor yang Mempengaruhi Pembelajaran Guru PAUD Jabodetabek Tahun 2014/2015" dapat memecahkan permasalahan pendidikan anak usiadini.

\section{Tujuan}

Berdasarkan latar belakang dan permasalahan di atas maka tujuan penelitian ini adalah sebagai berikut:

(1) Untuk mengetahui gambaran pembelajaran guru PAUD Jabodetabek sehingga dapat diperkirakan dampak pendidikannya terhadap anak dalam pengembangan potensi anak secara holistik.

(2) Untuk mengetahui faktor-faktor apa saja yang mempengaruhi pembelajaran guru
PAUD Jabodetabek sehingga dapat faktor-faktor negatif yang berdampak pada anak dapat diminimalisir.

(3) Untuk mengetahui apakah yang melatar belakangi perbedaan pola guru PAUD Jabodetabek dalam pembelajaran PAUD.

\section{Ruang Lingkup}

Adapun bentuk kegiatan adalah pelatihan parenting, dengan fokus pada perkembangan aspek psikososial dalam bentuk pendidikan karakter serta pelatihan terkait perkembangan kognitif anak melalui Pelatihan Orangtua Anak Usia Dini. Pelaksanaan pelatihan akan dibagi menjadi beberapa sesi pertemuan agar dapat memberikan waktu bagi para peserta untuk mengaplikasikan materi yang diperoleh dan dievaluasi pada pertemuan berikutnya.

\section{TINJAUAN PUSTAKA}

\section{Kurikulum Pendidikan Anak Usia Dini}

Orang tua dan masyarakat umumnya melihat keberhasilan belajar melalui sesuatu yang mudah diamati seperti membaca, menulis dan berhitung. Hal ini ironis sekali dengan kenyataan bahwa permasalahan yang ditimbulkan anak justru disebabkan karena kurangnya perhatian pada hal-hal yeng bersifat abstrak seperti sosial, emosial, seni yang menjadi bagian yang tidak terpisahkan dari pembelajaran anak usia dini. Berkaitan dengan itu Schikendanz (2001:xix) mengemukakan bahwa manusia tidak sama dengan mobil yang dapat dipereteli untuk dianalisis dan kemudian digabung kembali. Anak sebagai manusia utuh, hidup dengan dunianya, berkembang sesuai dengan pengalaman yang dialaminya secara individual. Akumulasi pengalaman anak membuat anak seperti adanya hari ini dan seperti apa adanya besok hari. Setiap perilaku dan karakteristik anak harus mempertimbangkan perkembangan sebelumnya dan prediktor-prediktor yang mempengaruhinya.

Pembelajaran terjadi karena kebanyakan nilainilai dan pelaksananan program pendidikan anak tumbuh dari nilai yang diperoleh anak dalam suatu masyarakat yang dilaksanakan secara turun temurun (Feeney, 2006:55).Nilainilai yang diadopsi secara turun temurun ini juga dipengaruhi oleh pemimpin agama, pembaharu masyarakat, dan pendidik di masa 
lalu. Untuk itu Feeney mengemukakan dua prinsip dalam menyediakan pendidikan bagi anak agar hasil pendidikan dapat lebih didayagunakan: pertama, prinsip kesesuaian pendidikan yaitu dengan menyediakan pendidikan sesuai dengan tingkat perkembangan, kemampuan dan kebutuhan.

Kurikulum merupakan jawaban dari kebutuhan anak. Melalui kurikulum, pengembangan anak dapat dilakukan sesuai dengan harapan dan tuntutan masyarakat. Oleh karena itu maka kurikulum dalam pemahaman yang luas tersebut merupakan pengalaman penting berupa ide-ide, siapa pendidik, apa yang telah dilakukan pendidik, dan bagaimana pendidik tersebut mempengaruhi kehidupan anak. Zais (1976:08) menambahkan bahwa kurikulum adalah blue print untuk pendidikan,yang memuat pengalaman-pengalaman yang penting dan terencana untuk anak.

Menurut Kurikulum didefinisikan oleh Arce (2000:02) sebagai keseluruhan pengalaman yang berkaitan dengan sekolah yang berpengaruh pada anak. Dengan perkataan lain, kurikulum adalah pengalaman-pengalaman baik pengalaman yang direncanakan maupun pengalaman yang tidak direncanakan dan kurikulum merupakan hasil dari nilai-nilai dan sikap-sikap dari guru, tenaga kependidikan, keluarga dan masyarakat.

Sementara itu dalam UU RI No 20 Tahun 2003 tentang Sistem Pendidikan Nasional pasal 1 ayat 19 dikemukakan bahwa definisi kurikulum adalah seperangkat rencana dan pengaturan mengenai tujuan, isi, dan bahan pelajaran serta cara yang digunakan sebagai pedoman penyelenggaraan kegiatan pembelajaran untuk mencapai tujuan pendidikan tertentu.

Menyimak pengertian yang dikemukakan di atas maka kurikulum bagi anak usia dini adalah semua pengalaman yang mempengaruhi anak yang terkait dengan sekolah baik yang direncanakan maupun yang tidak direncanakan serta hasil dari nilai-nilai dan sikap guru, staf, keluarga, dan masyarakat. Mengingat begitu luasnya pihak yang mempengaruhi anak, maka kurikulum anak usia dini semestinya menggambarkan keluaran pendidikan yang dapat menjadi bekal bagi anak untuk masa depan.
Ketika kelak anak menjadi dewasa maka ia akan membutuhkan kemampuan-kemampuan dalam hidupnya, yang menurut Gestwicki (2007:08) berupa: (1) kemampuan berkomunikasi dengan baik, menghargai dan berhubungan dengan orang yang mempunyai pendapat dan fungsi yang berbeda-beda sebagai anggota suatu masyarakat; (2) kemampuan menganalisa situasi, membuat pertimbangan yang masuk akal, dan memecahkan masalah yang dihadapi; (3) dapat mengakses informasi dari berbagai sumber, meliputi berbicara menulis dan menggunakan alat dan teknologi yang lebih kompleks dan sedang berkembang; dan (4) secara terus menerus mempelajari pendekatan, keterampilan, dan pengetahuan yang baru sesuai dengan kondisi dan perubahan. Semua hal yang dikemukan oleh Gestwicki ini tidak berarti bahwa anak usia dini diberikan informasi yang sama dengan orang dewasa tetapi anak usia dini perlu fondasi untuk menopang kenyataan yang akan mereka temukan di masa depannya nanti.

Pengembangan watak anak sebagaimana yang dikemukakan di atas maka NAEYC dalam DAP memberikan pernyataan bahwa pentingnya ide-ide kurikulum sebagai berikut: (1) pemahaman tentang anak mesti dikaitkan dengan konteks keluarganya, budayanya, dan masyarakat di sekelilingnya, (2) anak dan orang dewasa perlu dibantu untuk mengembangkan potensi yang dimilikinya dalam berhubungan dengan orang lain atas dasar kepercayaan, penghargaan, dan sikap positif serta menghargai dan mengakui keunikan masing-masing anak (Arce, 2000:03).

Makna dan nilai merupakan modal dasar untuk mengembangkan diri anak sesuai dengan perkembangannya kerena itu anak harus diterima sebagaimana adanya. Senada dengan itu Buchfield (1999:154) mengemukakan bahwa anak harus diterima sebagaimana adanya sebagaimana orang dan pelajar dan ditantang untuk bergerak ke depan berdasarkan kemampuan yang telah dimilikinya.

Berhubungan dengan kurikulum yang bermakna sebagaimana yang dikemukakan di atas, Bredekamp dan Rosegrant (1999:32) mengemukakan bahwa kurikulum akan bermakna bagi anak apabila: (1) kurikulum sesuai dengan gaya dan siklus anak-anak belajar, (2) perhatikan anak secara keseluruhan 
dan kemudian tetapkan kegiatan sesuai dengan kecenderungan anak, (3) pahami anak secara mendalam dan kembangkan konsep yang terintegrasi dengan pengalaman-pengalaman sebelumnya, (4) perhatikan apakah kegiatan sesuai dengan kebutuhan dan minat anak, (5) apakah kegiatan mengacu kepada pengetahuan berbasis disiplin dan mempunyai integritas intelektual, dan merupakan hasil dari pengajaran interaktif.

Prinsip-prinsip kurikulum akan memandu pengajaran dan pembelajaran dengan cara yang paling sesuai dengan anak usia dini dan dipastikan dapat menjadikan fondasi yang kokoh untuk membangun tahapan pembelajaran berikutnya. Pengembangan pendidikan harus menyentuh pikiran dan hati. Oleh karena itu, pendidik perlu memahami bagaimana anak belajar yaitu melalui observasi, eksplorasi, imaginasi, penemuan, penyelidikan, mengumpulkan informasi dan berbagi informasi dari lingkungan yang dekat dengan dirinya (Ministry of Education Singapore, 2003:10).

\section{Kajian Teori Belajar Melalui Bermain}

Setiap anak yang mengikuti kegiatan belajar mengajar di kelas belum tentu mengalami belajar. Oleh karena itu Gartrell (2003:36) mengartikan belajar sebagai apa yang dilakukan individu ketika ia menkonstruksi secara mental makna dari informasi. Belajar adalah pemerolehan pemahaman yang terjadi dalam domain-domain fisik, emosional, kognitif, sosial dan budaya. Proses tempat terjadinya pembelajaran adalah pendidikan baik pendidikan di rumah, di kelas dan di lingkungan. Penjelasan ini menunjukkan bahwa anak memperoleh pemahaman dalam domain fisik, emosional, kognitif, sosial dan budaya anak. Dengan demikian, dukungan terhadap anak dalam bentuk motivasi penting artinya dalam menstimulasi anak dalam belajar. Pengajaran dan pengalaman belajar bagi anak merupakan proses pemaknaan, dimana anak mengembangkan rasa memiliki, rasa kebanggaan, dan pengetahuan.Pembelajaran bukan hanya sesuatu yang dilakukan anak di sekolah tetapi pilihan-pilihan yang terjadi sepanjang hayat (Burchfiled, 1999:157)

Selanjutnya Froebel dalam Brewer (2007:41) mengatakan bahwa permainan dalam pendidikan anak usia dini merupakan fondasi bagi pembelajaran anak sehingga dapat menjembatani anak antara kehidupan di rumah dan kehidupan anak di sekolah. Kebutuhan perkembangan anak dapat dipahami melalui pemamahaman tentang bagaimana anak berubah baik perubahan dalam bentuk fisik, perilaku, dan perubahan dalam karakteristik berpikir. Mengajar anak dengan baik berarti pendidik harus mempelajari anak itu sendiri (Arce, 2000:07). Oleh karena itu, peran orang tua dari pespektif perkembangan anak dikatakan sebagai bagaimana orang tua memfasilitasi, menyokong dan membantu berkembang sesuai dengan kebutuhan anak, tidak berdasarkan kepada kebutuhan orang tua (Essa, 2003:64).

Sehubungan dengan permasalahan tersebut di atas Wolfgang (1992:17-18) menyarankan: "jika anda ragu dalam memilih metoda mengajar yang paling baik, apakah pengajaran langsung atau pengajaran berbasis permainan". Salah satu caranya adalah dengan sedikit merubah pertanyaan tersebut, "metoda manakah yang melakukan praktek sesuai perkembangan anak?". Senada dengan itu Barrel (1995:06) mengemukakan bahwa kebijaksanaan dalam pengajaran penggunaan konsep pemikiran dalam memaknai pengajaran secara penuh tentang tujuan, strategi dan pilihan-pilihan. Guru yang bijak terbuka terhadap ide yang baru dan tidak terjebak oleh kebiasaan dan rutinitas dan memikirkan segala sesuatunya secara cermat. Guru yang bijak, berupaya mengintegrasikan pikiran dengan perasaan.

Filosofi pendidikan seringkali disalah artikan oleh berbagai pihak termasuk guru. Kegiatan berpusat pada anak seringkali diartikan bahwa anak yang menentukan atau anak mendikte pendidik padahal tujuan kurikulum beorientasi anak mengandung pengertian bahwa keputusan yang diambil dalam pengembangan kurikulum diarahkan sesuai dengan kebutuhan anak dan dengan cara-cara yang sesuai bagi pembelajaran anak tersebut. Esensi dari kurikulum berpusat pada anak adalah pendekatan yang menekankan kepada anak secara utuh (Bredekamp dan Rosegrant, 1999:36)

Pernyataan Gestwicki ini sekaligus menjawab keraguan para ahli pengembangan kurikulum sebagaimana dikemukakan oleh Kessler yang 
mempertanyakan apakah perkembangan anak merupakan kurikulum atau hanya merupakan penentu kurikulum atau hanya sebagai bahan pertimbangan agar praktek sesuai dengan perkembangan (Bredekamp dan Rosegrant, 1999:05). Selanjutnya Espinosa (1999) mengemukakan bahwa praktek sesuai perkembangan anak belum dapat dijadikan sebagai sebuah bukti bahwa guru telah mendidik anak sesuai dengan perkembangan mereka. Lebih jauh dari itu, guru harus mempunyai pemahaman yang mendalam tentang bagaimana anak belajar, termasuk apa yang penting bagi anak untuk dipelajari (Espinosa, 1999:163).

\section{Kurikulum Terintegrasi}

Pebelajaran selama ini lebih berorientasi kepada pengembangan pembelajaran permata pelajaran. Perkembangan pembelajaran yang mengaitkan satu mata pelajaran dengan mata pelajaran lain merupakan pendekatan yang terintegrasi dari berbagai mata pelajaran dalam suatu aktivitas tertentu. Sehubungan dengan integrasi Drake (2007:25) menemukan bahwa integrasi dan interdisiplin seringkali dipertukarkan dalam penggunaannya yang menggambarkan suatu kurikulum yang memnghubungkan berbagai disiplin dalam cara tertentu.

Berkaitan dengan itu Drake (2007:25) kurikulum terintegrasi dapat dilihat dari berbagai cara, dan implementasi kurikulum terntegrasi juga bersifat unik sesuai dengan settingnya. Secara umum kombinasi berbagai subjek dapat diintegrasikan sesuai dengan keinginan guru-guru yang terlibat. Barangkali seorang guru mengajar beberapa mata pelajaran melalui konsep atau tema yang bersifat umum. Atau kurikulum terintegrasi barangkali tim guru yang mengkombinasikan kawasan yang dikemukakan oleh para ahli. Kurikulum terintegrasi melalui pendekatan interdisiplin tidak dapat distandarisasikan atau bahkan sering merupakan replikasi atau contoh yang ditiru oleh guru-guru yang lain karena ingin melakukan hal yang sama. Berkaitan dengan itu maka guru harus kreatif, mengembangkan kurikulum sesuai dengan konteks yang relevan. Guru juga dapat mengembangkan kurikulum terintegrasi sesuai dengan kebutuhan anak atau meminta input dari anak tentang apa yang inginmereka pelajari. Cara-cara untuk menghubungkan antar area subjek bersifat terbatas.

Selanjutnya Schickendanz (2008:03) memakai istilah integrasi lintas domain dalam mengemukkan kurikulum terintegrasi. Lintas domain adalah satu cara untuk mengintegrasikan kurikulum dengan menggabungkan dua atau lebih domain konten dalam suatu aktivitas instruksional dan konteks pembelajaran. Untuk memperkuat Schickendanz mengemukkan bahwa disamping lintas domain diperlukan integrasi lintas setting. Integrasi lintas setting merupakan penggabungan yang memberikan kesempatan pada pembelajaran anak dalam domain tertentu atau dalam domain ganda yang didukung melalui setting yang bervariasi dalam kegiatan sehari-hari.

Lebih jauh lagi Schickendanz (2008:01) mengemukakan bahwa pengintegrasian pembelajaran dalam domain konten ganda dan konteks pembelajaran yang beragam dapat membantu guru dalam mengelola waktu dan membuat pembelajaran lebih kuat dan bermakna bagi anak. Selanjutnya menurut Hendrik dan Osborn dalam Kostelnik (1991:02) mengemukakan bahwa tema membantu anak mengembangkan keseluruhan sensorinya dalam mengarahkan dan mengkonsolidasikan pembelajarannya, Melalui tema berbasis program, anak membangun hubungan antara bagian-bagan informasi yang terbentuk abstrak sampai dengan konsep yang kompleks.

Mengingat pentingnya pembelajaran terintegrasi baik terintegrasi domain dan setting pembelajarannya sehingga anak dapat mengoptimalkan kemampuannya melalui akivitas yang beragam. Berkaitan dengan aktivitas anak tersebut Rae (2007:xi) mengemukakan anak dan gerak, perkembangan fisik merupakan hal utama dalam pembelajaran anak, untuk itu ada beberapa hal yang perlu dipertimbangkan bahwa: (1) anak belajar dengan lebih apabila belajar melalui melakukan, seperti bermain, melakukan eksperimen, ekplorasi dan penemuan, (2) anak belajar secara utuh berarti anak belajar menggunakan pikiran, perasaan, gerak manusia yaitu belajar melalui sensorinya, (3) gerakan tubuh dapat memengaruhi kesehatan emosional anak, 
kemampuan belajar, dan kinerja intelektual anak, dan (4) anak akan dapat berpkir dengan baik apabila dalam rutinitasnya sehari-hari menggunakan aktivitas fisik. Berkaitan dengan itu maka konteks pembelajaran merupakan bagian penting dalam mendorong anak untuk belajar lebih mandiri dan bereksplorasi dengan lebh bebas dalam upaya optimalisasi potensi yang dimilikinya.

Mengacu kepada pentingnya akativitas anak dalam gerak maka dapat dipahami bahwa Fogarty memakai istilah keterampilan dalam integrasi kurikulum. Menurut Fogarty (1991:xiii) secara spesifik memakai istilah intergrasi keterampilan, tema-tema, konsepkonsep dan topik-topik interdisiplin yang sama diketahui. Hubungan yang ekplisit ini digunakan untuk mendorong pembelajaran dalam bentuk perilaku yang bersifat holistik sehingga anak dapat menghubungkan ide-ide dari suatu subjek kepada ide dalam suatu subjek lainnya. Penggunaan tema ini menurut Kostelnik (1991:02) berkembang setelah Dewey mengaitkan kehidupan nyata ke dalam kurikulum. Dalam pengembangan sebuah tema, guru memilih topik yang diyakininya relevan dan diminati oleh anak, kemudian dibangun pembelajaran terkait dengan ide utama tersebut.

Lebih jauh Schickendanz (2008:02) mengemukakan bahwa kekuatan kurikulum terintegrasi adalah untuk meningkatkan keseluruhan domain yang terintegrasi secara keseluruhan. Untuk itu pengintegrasian pembelajaran guru harus: (1) memastikan mengambil tindakan untuk mendukung pembelajaran dalam satu domain tidak mengabaikan pembelajaran pada domain lainnya, (2) mempertimbangkan timing dalam melakukan integrasi, (3) mempertimbangkan urutan pembelajaran anak dan pengetahuan yang dimilikinya dalam domain yang dipelajari, (4) memikirkan secara seksama tentang penekanan yang diberikan pada setiap domain, (5) empertimbangkan integrasi tidak hanya dalam satu pengalaman istruksional, tetapi juga lintas domain dan pengalaman instruksional terkait, dan (6) berpikir secara strategis tentang penggunaan konteks pembelajaran ganda, seperti klasikal, kelompok kecil atau saat di sentra.

Bredekamp dalam Kostelnik (1991:02) mengemukakan beberapa prinsip dalam pengembangan dan pengimplementasian tematik yaitu: (1) mengembangkan pengalaman lansung pada objek untuk diperhatikan atau digunakan, (2) mengembangkan aktivitas yang melibatkan seluruh sensori anak, (3) membantu anak mengembangkan pengetahuan baru melalui apa yang telah diketahui dan tekah dilakukan anak sebelumnya, (4) mengembangkan aktivitas dan rutinitas yang melibatkan semua aspek perkembangan baik kognitif, sosial, emosional, dan fisik, (5) mengakomodasi kebutuhan anak akan gerak dan aktivitas fisik, interaksi sosial, kemandirian, self esteem positif, (6) memberikan kesempatan untuk menggunakan bermain untuk menterjemahkan pengalaman ke dalam pemahaman, (7) menghargai perbedaan individual, latar belakang budaya, dan pengalaman anak di rumah yang terbawa anak ke sekolah, dan (8) menemukan cara untuk melibatkan anggota keluarga anak.

Dari uraian yang dikemukan di atas dapat dikemukakan bahwa integrasi domain dalam kurikulum seyogianya diperkuat dengan integrasi setting sehingga anak. Melalui integrasi doamin dan setting dapat diptimalkan efektivitas tujuan kurikulum sekaligus anak memperoleh aktivitas dari berbagai setting yang dapat mengakomodasi berbagai gaya belajar anak. Efektivitas dan efisiensi pembelajaran untuk mengptimalkan potensi anak sangat dipengaruhi oleh pengembangan konteks belajar yang ada di lembaga PAUD tempat anak dididik dan lingkungan keluarga dimana anak dibesarkan.

\section{Konteks Pembelajaran Klasikal}

Setiap pendekatan pembelajaran mempunyai karakteristik sendiri-sendiri. Menurut Schickedanz (2008:55) aktivitas yang bersifat klasikal dapat berupa bernyanyi bersama, membaca puisi bersama, diskusi kelompok tentang fieldtrip, sementara guru memandu dan mendorong anak untuk menceritakan pengalamannya. Untuk membuat diskusi lebih menarik guru dapat menyertakan media dan buku bergambar lainnya.

Schickedanz (2008:56) Langkah-langkah dalam pembelajaran klasisikal yaitu: (1) mempersiapkan pengorganisasian aktivitas dan materi-materi ajar, (2) cerita guru yang manantang, dengan konten yang kaya dan penuh dengan penjelasan serta pertanyaan yang 
kritis, (3) menggunakan kosa-kata yang dimengerti oleh anak, (4) menghidarkan diri dari percakapan yang panjang dengan satu anak (memperhatikan anak secara keseluruhan). Selengkapnya dapat dilihat pada tabel berikut:

Schickedanz (2008:57) Dalam perencanaan tiap siklus sehari-hari, guru mempertimbangkan variasi baik dalam tujuan pembelajaran, lama waktu pembelajaran dan perilaku yang dituntut pada anak. Guru memberikan panduan secara substansi pembelajaran yang diasosiakan melalui lagu atau sajak. Disamping itu lagulagu dan sajak diikuti dengan gerakan atau tindakan-tindakan tertentu. Pengulanganpengulangan dan dukungan secara fisik dan visual oleh guru dalam mempelajari lagu-lagu dan sajak bagi anak sehingga anak ikut kegiatan dengan rasa nyaman dan aman dalam menampilkannya.

Schickedanz (2008:59) Pada saat lingkaran, guru menyeleksi aktivitas-aktivitas yang bervariasi dan secara seksama mempertimbangkan bagaimana urutan aktivitas cocok dengan kebutuhan anak di kelompoknya dan membuat anak tertarik dan terlibat dalam kegiatan. Kegiatan tersebut dapat antara lain dapat berupa: (1) aktivitas berdiri dan duduk, (2) aktivitas yang melibatkan tindakan dan berbicara dan aktivitas-aktivitas yang hanya melalui menyimak dan berbicara, (3) aktivitasaktivitas yang bergiliran dan yang tidak bergiliran, (4) aktivitas-aktivitas yang dikenal oleh anak dan aktivitas yang kurang dikenal anak atau aktivitas yang sama seklai baru bagi anak, dan (5) aktivitas dengan bentuk yang berbeda dan tingkat tantangannya bagi anak untuk berpikir.

Schickedanz (2008:56) Pertama, hasil penelitian McCartney (1984) terhadap dampak pembelajaran klasikal diantaranya padaa saat lingkaran pembelajaran lebih produktif. Dibeberapa pra sekolah yang dilaksanakan secara klasikal utamanya yang menyelenggaran cerita dan saat lingkaran menunjukkan bahwa pembelajaran bahasa anak lebih tinggi sementara pada saat guru bercerita lebih bersifat informatif dan kurang terfokus pada larangan-larangan, dan arahan-arahan dari guru. Kedua, hasil kajian Dickinson (2001) percakaan yang bersifat informatif dan percakapan yang menantang di pra sekolah berkaitan erat dengan hasil belajar bahasa yang lebih baik. Ketiga, Hasil penelitian Klibanoff et al, (2006) menemukan bahwa terdapat hubungan yang kuat antara penggunaan kosa kata Matematika dengan pemahaman tentang matematika pada saat lingkaran denganketerampilan dan pemahaman Matematika anak dari tahun ke tahun.

\section{Konteks Pembelajaran Sentra}

Schickedanz (2008:81) Saat di sentra paling tidak selama 55-60 menit. Selama berada disentra, anak dapat memilih mengikuti berbagai macam aktivitas di area yang berbeda-beda. Secara khusus sentra dapat berupa sentra balok, drama, membaca, puzzle, matematika sains, seni dan lain sebagainya. Anak dapat bermain dengan teman-temannya di berbagai area, atau kelompok kecil yang mereka pilih sendiri walaupun jumlah anak dalam suatu sentra umumnya telah ditentukan oleh guru.

Schickedanz (2008:82) Guru dengan aktif terlibat selama saat di sentra, tetapi guru tidak boleh menggunakan sentra untuk pengajaran secara formal. Bahkan guru mengikuti keinginan anak dan merespon anak dengan cara-cara memberi dukungan terhadap pilihanpilihan yang dilakukan oleh anak. Hasil penelitin menunjukkan bahwa terdapat kaitan antara peningkatan pemahaman bahasa anak dengan pembicaraan guru dengan anak pada saat di sentra. Secara khusus juga ditemukan bahwa tingkat kepahaman bahasa yang tinggi antara anak dan guru berhunbungan dengan tingginya frekuensi percakapan antara guru dan anak, utamanya apabila pembicaran antara guru dan anak tersebut bersifat substatif dan berhubungan dengan aktivitas pembelajaran yang dilakukan anak. Selanjtnya juga ditemukan bahwa terdapat kaitan guru yang berkualitas tinggi dan percakapan dengan anak selama pembelajaran dengan pemahaman membaca anak pada tingkat 4 .

Schickedanz (2008:83) Selama di sentra, guru bergerak ke sekeliling kelas berinteraksi dengan anak untuk mendukung pekerjaan dan permainan yang dilakukan oleh anak. Di sentra sering dirancang agar satu atau dua guru dapat bergerak dan berada pada area tertentu sehingga kegiatan anak terus mendapatkan dukungan dari guru. Pergerakan guru di sekeliling kelas mendukung alur aktvitas dan 
dapat membantu hal-hal khusus yang menjadi perhatian atau pertanyaan anak. Dimana tempat guru berada juga dapat mengamati sentra yang dekat dengan dirinya. Tentu saja, dinamisasi kealamiahan guru saat di sentra berkomunikasi satu dengan yang lainnya dan menentukan pergerakannya dan perannya dimana diperlukan penting untuk diketahui oleh guru.

Isbell (1995:17) mengemukakan bahwa anak usia dini sebagai pembelajar aktif belajar melalui meraba, merasakan, berskperimen dan mencipta. Sentra yang efektif didisain untuk menghubungkan dunia anak sebagai pebelajar aktif dan perencanaan untuk mendorong keterlibatan anak dalam pembelajaran. Anak usi dini tertarik dengan dunia dilingkungan dia hdup; sentra merupkan representasi simbolik dunia mereka. Dalam dunia sentra ini anak dapat mencobakan berbagai ide dan menata ulang kejadian-kejadian yang sesuai dengan tingkat pemahamannya. Di dalam lingkungan sentra, anak dapat membangun rasa percaya dirinya dan mulai menyadari bahwa ia merupakan pebelajar yang memunyai kemampuan. Di dalam sentra anak juga dapat bekerjasama, memamukan anak berinteraksi lebih sering daripada dari kelompok besar. Anak-anak bekerjasama pada saat memperoleh respon awal terhadap ide-idenya, berkomunikasi dan bekerja.

Isbell (1995:17) bermain merupakan salah satu komponem penting dalam menentukan kualitas program pendidikan anak usia dini; bermain merupakan pekerjaan anak dan anak menginginkan bermain. Dalam bermain anak mengembangkan keterampilan memecahkan masalah dengan mencoba berbagai cara dalam melakukan sesuatudan dalam menentukan pendekatan yang paling tepat. Dalam bermain, anak menggunakan bahasa dalam melaksanakan aktivitas mereka, mengembangkan dan menyeleksi bahasa pada saat berbicara dan menyimak anak lainnya. Ketika bermain, mereka mempelajari tentang orang lain dan pada saat yang sama mencoba berbagai peran dan berusaha bekerjasama sama dengan orang. Bermain bermanfaat bagi perkembangan anak baik secara intelektual, sosial /emosional dan fisik.

Isbell (1995:18) dalam lingkungan kelas anak usia dini didisain untuk mengembangkan perkembangan anak secara keseluruhan. Aktivitas di kelas memberikan kepada anak untuk terlibat secara individual, dalam tim dan kelompok kecil. Aktivitas tersebut baik diarahkan oleh guru atau pilihan anak sendiri. Sentra merupakan komponen khusus, (1) sentra memberikan kesempatan pada anak untuk memilih aktivitas sendiri, (2) Disentra anak berkesempatan berinteraksi dengan anak lain, (3) di sentra anak memperoleh kesempatan bekerja secara individual dan dengan berpasangan, membantu anak untuk menjadi lebih mandiri atau belajar bekerja dengan bekerjasama.

Isbell (1995:20) sentra merupakan tempat pengintegrasian pembelajaran yang terbaik. Anak berbicara (bahasa oral), menggunakan keterampilan motorik halus (koordinasi bersifat fisik), bekerja bersama dalam proyek bersama (keterampilan sosial), memilih piring pada disimpat (Matematika), menemukan bagaimana membuat tempat mandi bagi bayi (sain), mengikuti arah gambar untuk menyimpan balok (membaca) dan membuat daftar barang belanjaan (menulis). Pembelajaran terjadi pada seluruh are perkembangan selama berada dalam sentra, dengan cara-cara yang bermakna yang cocok bagi pembelajaran anak usia dini.

\section{METODOLOGI PENELITIAN}

Penelitian ini bersifat deskriptif analitik, yaitu data dideskripsikan dengan menggunakan statistik deskriptif, dan dimaknai secara mendalam berdasarkan perspektif emik yaitu penyajian data secara alamiah tanpa melakukan suatu manipulasi atau perlakuan terhadap subjek yang diteliti (Bogdan dan Taylor, 1975:31). Disamping itu data deskriptif yang diisi oleh pengurus dan pendidik PAUD diperkuat melalui triangulasi data melalui observasi dan wawancara pada pengurus dan pendidik PAUD, orang tua, dan masyarakat sekitar sekolah.

\section{Waktu dan Tempat}

Penelitian dilaksanakan di 20 PAUD yang berada di di Wilayah Jabodetabek. Sedangkan waktu penelitian berlangsung selama 9 (sembilan) bulan, yaitu dari bulan Maret 2015Nopember 2015. 


\section{Ruang Ligkup dan Objek Penelitian}

Penelitian ini merupakan penelitian deskriptif kualitatif dengan ruang lingkup dan objek penelitian meliputi hal-hal sebagai berikut:

1. Wilayah penelitian dibatasi pada 20 lembaga PAUD dengan kriteria:

2. Berlokasi di Jabodetabek

3. Memiliki ijin pendirian dan ijin operasional

4. Sasaran Penelitian adalah guru-guru PAUD untuk mengetahui kecederungannya dalam pembelajaran.

5. Penelitian hanya mengkaji Guru PAUD yang mewakili sebagai pengajar di wilayah Jabodetabek.

\section{Alat dan Pengumpul Data}

Alat pengumpulan data yang digunakan dalam penelitian ini adalah lembar observasi dan panduan wawancara.

\section{Pengolahan dan Analisis Data}

Pengolahan data selanjutnya diolah dan dianalisis dengan menggunakan analisis kualitatif.

\section{HASIL DAN PEMBAHASAN}

\section{Hasil Penelitian}

\section{Temuan Umum}

Pembelajaran guru PAUD untuk wilayah Jabodetabek memiliki kekhasan dalam konteks pembelajaran. Konteks pembelajaran setiap lembaga PAUD dipengaruhi dalam berbagai factor seperti sarana dan prasarana sekolah, pendidik, tenaga kependidikan, dan factorfaktor psikologis lainnya. Tiga konteks pembelajaran dalam penelitian ini yaitu pembelajaran klasikal, pembelajaran sentra, dan pembelajaran kelompok kecil.

Setelah data dikumpulkan, maka pengolahan data selanjutnya diolah dan dianalisis dengan menggunakan analisis statistic deskriptif dan analisis kualitatif. Analisis Statistik Deskriptif dimana data angket yang diisi oleh responden dianalisis dengan statistic deskriptif guna melihat kecendrungan data tentang persepsi responden sedangkan analisis kualitatif merupakan penjelasan secara deskriptif dari hasil wawancara dan observasi responden.
Data hasil dari tes yang berupa data statistik tersebut kemudian diolah menggunakan program Microsoft Excell. Teknik observasi dilakukan dengan cara melakukan pengamatan dalam proses pembelajaran sesuai dengan konteks pembelajaran yang dilakukan. Data yang terkumpul melalui observasi merupakan data kuliatatif. Pengumpulan data obesrvasi ini menggunakan pedoman observasi. Teknik wawancara yang digunakan dalam penelitian inidigunakan untuk mengumpulkan data berupa jawaban pertanyaan dari butir-butir pertanyaan terhadap konteks pembelajaran yang digunakan dalam proses pembelajaran yang dijawab oleh guru dan kepala PAUD atau kepala TK.

\section{Temuan Khusus}

Berikut ini hasil temuan dalam penelitian Pembelajaran Guru PAUD Jabodetabek: Studi terhadap Faktor-Faktor yang Mempengaruhi Pembelajaran Guru PAUD Jabodetabek Tahun 2014/2015

\section{Gambaran Umum Luas Tanah Lembaga PAUD}

Rata-rata luas tanah lembaga PAUD dari 21 lembaga PAUD adalah $579.14 \mathrm{~m}^{2}$ dari 4 lembaga PAUD yang memiliki luas tanah $1500 \mathrm{~m}^{2}-2500 \mathrm{~m}^{2}$ dan 17 lembaga PAUD yang memiliki luas tanah $100 \mathrm{~m}^{2}-650 \mathrm{~m}^{2}$. Peraturan Menteri Nomor 137 Tahun 2013 tentang Standar Nasional PAUD pasal 32 menjelaskan bahwa persyaratan pendirian PAUD haruslah memiliki luas lahan minimal $300 \mathrm{~m}^{2}$ (untuk bangunan dan lahan).

\section{Gambaran Umum Luas Bangunan Lembaga PAUD}

Rata-rata luas bangunan lembaga PAUD dari 21 lembaga PAUD adalah $258.95 \mathrm{~m}^{2}$. Standar Nasional PAUD yang menjelaskan luas minimal $300 \mathrm{~m}^{2}$ (untuk bangunan dan lahan) dengan masing-masing ruang kegiatan yang man dan sehata dengan rasio minimal $3 \mathrm{~m}^{2}$ per anak dan tersedia fasilitas cuci tangan dengan air bersih, memiliki ruang guru, memiliki ruang kepala, memiliki ruang temapat UKS dengan kelengkapan P3K, memiliki jamban dengan air bersih yang mudah dijangkau anak, memiliki fasilitas bermain di dalam dan di luar, memiliki alat permainan edukatif yang aman dan sehat sesuai dengan SNI, dan memiliki tempat sampah yang tertutup. 


\section{Gambaran Umum Jenis Layanan}

Rata-rata lembaga PAUD memiliki 1 jenis layanan PAUD dalam bentuk Taman KanakKanak (TK)/ RA/BA. Dalam Permen nomor 137 tahun 2013 pasal 36 ayat 2 jenis layanan terdiri dari:

a) Usia lahir - 2 tahun dapat melalui TPA dan atau SPS

b) Usia $2-4$ tahun dapat melalui TPA, KB, dan atau SPS

c) Usia $4-6$ tahun dapat melalui Taman Kanak-Kanak (TK)/ Raudatul Athfal (RA)/Bustanul Athfal (BA)

\section{Gambaran Umum Jumlah Murid}

Rata-rata jumlah murid dari 21 lembaga PAUD adalah 57 anak.

\section{Gambaran Umum Jumlah Guru}

Jumlah guru dari 21 lembaga PAUD adalah 132 guru dengan rata-rata 6 orang di setiap lembaga PAUD. Maka rasio untuk tiap lembaga PAUD dari hasil penelitian ini adalah 1: 8. Peraturan Menteri No.137 Tahun 2913 ayat 36 butir 4 menjelaskan bahwa rasio guru dan anak didik terdiri atas :

a) Usia lahir- 2 tahun : rasio guru dan anak $1: 4$

b) Usia 2-4 tahun : rasio guru dan anak 1:8

c) Usia 4-6 tahun : rasio guru dan anak 1: 15

\section{Gambaran Umum Pendidikan Guru}

Jumlah pendidikan guru di lembaga PAUD yang mengampu pendidikan Sarjana Pendidikan Anak Usia Dini 65 guru dari 21 lembaga PAUD. Sedangkan pendidikan guru yang lulus program Diploma 2 maupun Diploma 3 berjumlah 16 guru. Guru dengan lulusan SLTA dengan keterangan beberapa guru sedang meneruskan program strata satu berjumlah 6 guru. Kualifikasi akademik guru PAUD diatur dalam Permen Nomor 137 tahun 2013 pasal 25 yang berbunyi Kualifikasi Akademik Guru PAUD:

a) Memiliki ijazah Diploma emapat (D-IV) atau Sarjana (S1) dalam bidang pendidikan anak usia dini yang diperoleh dari program studi terakreditasi, atau

b) Memiliki ijazah diploma emapat (D-IV) atau sarana (S1) kependidikan lain yang relevan atau psikologi yang diperoleh dari program studi terakreditasi dan memiliki sertifikat Pendidikan Profesi Guru (PPG)
PAUD dari perguruan tinggi yang terakreditasi

Kualifikasi Akademik Guru Pendamping:

a) Memiliki ijazah D-II PGTK dari Program Studi terakreditasi, atau

b) Memiliki ijazah minimal Sekolah Menengah Atas (SMA) atau sederajat dan memiliki sertifikat pelatihan/ pendidikan/ kursus PAUD jenjang guru pendamping dari lembaga yang kompeten dan diakui pemerintah

Kualifikasi Akademik Guru Pendamping Muda

a) Memiliki ijazah Sekolah Menengah Atas (SMA) atau sederajat. Dan emiliki sertifikat pelatihan/ pendidikan/kursus PAUD jenjang pengasuh dari lembaga yang kompeten dan diakui pemerintah.

\section{Gambaran Umum Konteks Pembelajaran}

Hasil observasi yang dilakukan terhadap 21 lembaga PAUD, Konteks pembelajaran yang diterapkan lembaga PAUD Jabodetabek adalah Konteks Pembelajaran Klasikal. Menurut Schickedanz (2008:55) aktivitas yang bersifat klasikal dapat berupa bernyanyi bersama, membaca puisi bersama, diskusi kelompok tentang fieldtrip, sementara guru memandu dan mendorong anak untuk menceritakan pengalamannya. Untuk membuat diskusi lebih menarik guru dapat menyertakan media dan buku bergambar lainnya.

\section{Gambaran Pembelajaran Guru PAUD Jabodetabek}

Berdasarkan hasil angket yang diberikan kepada responden diketahui bahwa gambaran pembelajaran guru PAUD Jabodetabek lebih berorientasi kepada konteks pembelajaran klasikal. Dari 21 sekolah yang menjadi responden penelitian ini diketahui bahwa 18 sekolah (85,71\%) menggunakan konteks pembelajaran klasikal dan sekolah yang melakukan pembelajaran konteks pembelajaran kelompok kecil 1 sekolah (4,76\%), sedangkan sekolah yang menggunakan konteks pembelajaran sentra 2 sekolah $(9,52 \%)$. Selain itu juga ditemukan bahwa diantara sekolah yang menggunakan pendekatan utama klasikal ini diantaranya ada juga menggunakan pendekatan kelompok dan pendekatan sentra pada kegiatan-kegiatan tertentu. Namun yang menggunakan konteks pembelajaran klasikal 
dan konteks pembelajaran sentra sebanyak 1 sekolah $(4,76 \%)$.

Dilihat dari hasil angket terkait pelaksanaan konteks pembelajaran klasikal dapat dikemukakan dalam beberapa tahapan pembelajaran yaitu: (1) kegiatan awal, (2) kegiatan inti, dan kegiatan akhir:

Pertama, kegiatan awal dapat diketahui dengan beberapa kegiatan yang dilakukan diantaranya bernyanyi, membaca doa, absensi, penjelasan tema dan penerapan lingkaran (circle time). Dari hasil angket diketahui bahwa bernyanyi dan membaca doa merupakan kegiatan yang selalu dilakukan oleh 18 sekolah (85\%). Kegiatan absensi dan penjelasan tema dilakukan oleh 13 sekolah (76\%). Kegiatan puisi di dalam kelas adalah kegiatan hanya dilakukan 8 sekolah ( 38\%).

Kedua, kegiatan inti merupakan kegiatan dimana anak-anak sudah mulai melakukan berbagai aktivitas diantaranya guru harus menyediakan media untuk menjelaskan tema. Selain itu guru juga harus menyediakan aktivitas yang dilakukan oleh anak dan menyiapkan aktivitas yang tingkat kesulitannya lebih tinggi dibandingkan perkembangannya. Dari hasil angket dapat ketahui bahwa guru selalu meyiapkan aktivitas untuk dilakukan anak-anak dan anak-anak juga melakukan aktivitas yang dibuat guru serta guru mengawasi anak-anak selama anak-anak melakukan aktivitas. Sebanyak 18 sekolah $(85 \%)$ melakukan kegiatan tersebut. Tetapi masih jarang guru yang menerangkan aktivitas yang akan dilakukan anak-anak, serta meyiapkan kegiatan yang mengajarkan anak untuk antri. Terdapat 13 sekolah dari 21 sekolah $(76 \%)$. Sedikit sekali sekolah yang menyiapkan aktivitas yang tingkat kesulitannya lebih tinggi dibandingkan perkembangan anak, sebanyak 7 sekolah $(33,3 \%)$.

Ketiga, kegiatan akhir dalam pembelajaran merupakan kegiatan yang dilakukan setelah anak-anak melakukan istirahat (bermain dan makan bersama). Kegiatan akhir dapat dilakukan seperti membuat lingkaran, melakukan evaluasi pembelajaran kepada anak (menanyakan kegiatan apa saja yang telah dilakukannya hari ini), guru memotivasi anak untuk menyiapkan dirinya untuk dating ke sekolah esok hari. Dari hasil angket dapat diketahui 18 sekolah (85\%) dalam kegiatan akhir selalu dipimpin oleh guru. Anak belum menjadi bagian dari proses pembelajaran di akhir kegiatan. Guru sudah melibatkan anak dalam melakukan evaluasi maupun bercerita sebanyak 15 sekolah (71\%).

Dilihat dari hasil angket, terkait dengan konteks pembelajaran Sentra dapat dikemukakan dalam 4 lingkungan main: Pijakan Lingkungan Main (1) pijakan lingkungan sebelum main (2) pijakan lingkungan saat main (3) pijakan lingkungan setelah main

Pertama, pijakan lingkungan sebelum main mencakup beberapa kegiatan seperti membuat jurnal, menceritakan isi jurnal, guru meminta anak untuk membentuk lingkrang, melakukan do'a dan bernyanyi, guru mengingatkan aturan yang ada di sentra, dan menyiapkan anak untuk bermain. Dari hasil angket dapat dilihat 14\% guru sudah memperkenalkan sentra apa saja yang ada di sekolah. Konteks pembelajaran sentra sebanyak $9,5 \%$ anak sudah melakukan kegiatan jurnal maupun mencorat coret di kertas serta menceritakan kembali isi jurnal.

Kedua, lingkungan saat main merupakan kegiatan dimana anak sudah berada di dalam sentra. Di sana terdapat beberapa tempat main dimana anak-anak dapat melakukan berbagai aktivitas sesuai dengan sentranya. Di dalam konteks pembelajaran sentra, 19\% guru memotivasi anak untuk mengajukan pertanyaan-pertanyaan yang berkaitan dengan tema dan guru merespon anak dengan mencari dukungan terhadap pilihan-pilihan yang dilakukan oleh anak. Sebanyak 14\% guru yang melakukan konteks pembelajaran sentra sudah melakukan guru menyiapkan aktivitas yang akan dilakukan anak-anak di sentra, guru mengawasi anak-anak selama pembelajaran, guru mendorong minat anak untuk mendukung aktivitasnya baik dalam bentuk perhatian maupun pertanyaan, dan guru juga memotivasi minat anak untuk beraktivitas di sentra lain.

Ketiga, lingkungan setelah main merupakan kegiatan dimana anak-anak selesai melakukan aktivitas di sentra serta merapikan mainan yang digunakan ketika melakukan aktivitas (bersihbersih). Sebanyak 14\% guru sudah melakukan kegiatan di lingkungan setelah main. Kegiatan itu berupa melakukan recalling (mengkomunikasikan kegiatan yang dilakukan 
selama bermain), mendorong kepemimpinan di dalam sentra, guru membiasakan anak untuk mengungkapkan perasaannya setelah melakukan aktivitas. 19\% guru melakukan aktivitas bersih-bersih bersama-sama anakanak.

Konteks pembelajaran kelompok kecil dikemukakan dalam beberapa tahapan: (1) kegiatan awal, (2) kegiatan inti, (3) kegiatan akhir

Pertama, pada konteks pembelajaran kelompok kecil kegiatan awal pembelajaran ditandai dengan pembagian anak ke dalam kelompokkelompok kecil yang terdiri 4-5 anak, melakukan do'a, absensi, bernyanyi bersama. Sebanyak $14 \%$ guru melakukan kegiatan berdo'a, bernyanyi, dan kegiatan rutinitas lainnya.

Kedua, kegiatan inti pada konteks pembelajaran kelompok kecil dilakukan dengan penjelasan tema menggunakan media, melakukan aktivitas dengan kelompok kecil, guru memberikan respon terhadap anak-anak dalam kelompok kecil. Sebanyak 14\% guru sudah melakukan kegiatan di kelompok kecil seperti guru memberikan aktivitas di kelompok kecil dan meresponnya, guru menjelaskan tema, dan guru memotivasi kelompok kecil untuk bekerjasama menyelesaikan tugasnya.

Ketiga, kegiatan akhir dilakukan dengan mengevaluasi kegiatan apa saja yang telah dilakukan, $14 \%$ guru sudah melakukan evaluasi, guru bersama anak berdiskusi kegiatan apa saja yang dilakukan, dan berdo’a sebelum pulang.

\section{Faktor-Faktor yang Mempengaruhi Pembelajaran Guru PAUD}

Berdasarkan temuan umum dan temuan khusus, ada beberapa factor yang mempengaruhi pembelajaran guru PAUD, yaitu:

1. Dari hasil angket dapat diketahui bahwa $85 \%$ konteks pembelajaran yang diterapkan di PAUD menggunakan konteks pembelajaran klasikal, dikarenakan konteks pembelajaran klasikal sudah dilakukan sejak PAUD berdiri.

2. Terbatasnya luas sekolah menjadi salah satu factor yang mempengaruhi pembelajaran guru PAUD
3. Terbatasnya sarana dan prasarana yang tersedia di PAUD

4. Konteks pembelajaran klasikal dianggap dapat memenuhi kebutuhan anak.

5. Terbatasnya biaya menjadi salah satu factor yang mempengaruhi pemebelajaran guru PAUD

\section{Latar Belakang Perbedaan Guru PAUD Dalam Pembelajaran PAUD}

Dalam proses kegiatan belajar mengajar di PAUD, banyak hal yang melatarbelakangi perbedaan pembelajaran PAUD. Dari hasil wawancara yang dilakukan kepada guru maupun kepala PAUD, perbedaan tersebut dapat diketahui dari:

1. Fasilitas atau sarana dan prasarana yang tersedia di PAUD tersebut

2. Biaya menjadi salah satu hal penting yang menyebabkan sulitnya sekolah-sekolah mempunyai sarana prasarana yang sesuai dengan kebutuhan anak

3. Tenaga pendidik (guru) menyangkut kompetensi yang dimiliki tenaga pengajar dalam mengembangkan pembelajaran.

4. Materi, pengetahuan tenaga pengajar untuk bisa mengembangkan materi pembelajaran juga menjadi factor yang melatarbelakangi perbedaan pembelajaran

5. Jumlah siswa yang terlalu banyak menjadi salah satu factor yang melatarbelakangi perbedaan pembelajaran yang mengakibatkan pembelajaran menjadi kurang kondusif

\section{PEMBAHASAN}

Setelah melihat hasil angket dan wawancara maka peneliti akan membahas tentang factorfaktor yang mempengaruhi pembelajaran guru PAUD. 85\% konteks pembelajaran klasikal digunakan dalam pembelajaran PAUD. Dari hasil ini dapat kita ketahui bahwa sekolahsekolah yang sudah menerapakan konteks pembelajaran klasikal sejak berdirinya sekolah akan sulit sekali merubah konsep konteks pembelajaran yang baru. Sehingga sekolah beserta komponen yang ada di sekolah tersebut merasa sudah "nyaman" dengan konteks pembelajaran yang sudah diterapkan. Hal tersebut menambah keyakinan guru bahwa konteks pembelajaran yang sudah diterapkan sesuai dengan minat anak. Dengan alasan terbatasnya lahan dengan rata-rata luas tanah 
$579 m^{2}$. Menurut Peraturan Menteri Nomor 137 Tahun 2013 tentang Standar Nasional PAUD pasal 32 menjelaskan bahwa persyaratan pendirian PAUD haruslah memiliki luas lahan minimal $300 \mathrm{~m}^{2}$ (untuk bangunan dan lahan).

Sehingga dapat kita ketahui dengan rata-rata luas tanah $579 \mathrm{~m}^{2}$ dengan standar minimal luas lahan $300 \mathrm{~m}^{2}$, guru dapat mengeksplore lahan di sekolah untuk melakukan pembelajaran yang bermakna yaitu suatu proses pembelajaran yang efektif dan membawa pengaruh perubahan tingkah laku anak didik dalam mencapai kompetensi atau tujuan yang telah dirumuskan.

Sarana dan prasarana menjadi salah satu factor yang menjadi pengaruh pembelajaran PAUD. Sebaiknya guru dapat memfasilitasi sarana yang dibutuhkan oleh anak-anak dengan menggunakan barang-barang bekas. Hal tersebut dapat meningkatkan kreatifitas anak. Sarana prasarana yang minim juga akan mendongkrak pemikiran guru untuk menciptakan media atau aktivitas yang lebih kreatif dan edukatif.

Biaya merupakan salah satu factor yang mempengaruhi pembelajaran guru PAUD. Hal tersebut menjadi dasar pemikiran bahwa banyaknya lembaga PAUD yang berstatus swasta sehingga harus membiayai semua kegiatan pembelajaran yang dilakukan di lembaga PAUD. Fenomena yang terjadi sekarang ini dengan menjamurnya berdiri lembaga PAUD, menyebabkan persaingan biaya sekolah di lembaga PAUD. Dengan tujuan utama adalah memperoleh peserta didik sebanyak-banyaknya. Semakin murah biaya pendidikan anak usia dini akan semakin banyak peserta didik yang diperoleh.

Melihat konteks pembelajaran klasikal menjadi sangat dominan, dilanjutkan dengan konteks pembelajaran sentra, dan konteks pembelajaran kelompok kecil. Peneliti melihat latar belakang perbadaan guru PAUD dalam pembelajaran. Perbedaan tersebut dipengaruhi dari tenaga pendidik ( guru), ada empat kompetensi yang harus dimiliki oleh seorang guru menurut Permen No.137 tahun 2013, yaitu (1) kompetensi pedagogik, (2) kompetensi social, (3) kompetensi kepribadian, (4) kompetensi professional. Dalam hal ini seorang guru yang memiliki kompetensi pedagogik mampu merumuskan pembelajaran yang sesuai dengan minat dan perkembangan anak.

Seorang guru juga mampu mengembangkan materi yang akan dilakukan dalam kegiatan belajar mengajar. Bukan hanya mentrasfer ilmu tetapi seorang guru juga harus mampu memotivasi anak untuk mengeksplore materi. Sehingga pembelajaran menjadi lebih bermakna sesuai dengan prinsip pembelajaran anak usia dini. .

Biaya menjadi salah satu hal yang melatarbelakangi perbedaan pembelajaran guru PAUD. Telah kita bahas sebelumnya bahwa semakin "murah" biaya sekolah tersebut semakin banyak peserta didik yang masuk ke lembaga PAUD tersebut. Sehinga jumlah pendidik tidak mengikuti standar Peraturan Menteri No.137 Tahun 2913 ayat 36 butir 4 menjelaskan bahwa rasio guru dan anak didik terdiri atas : (1)Usia lahir- 2 tahun : rasio guru dan anak $1: 4$, (2)Usia 2-4 tahun : rasio guru dan anak 1:8,(3)Usia 4-6 tahun : rasio guru dan anak 1: 15. Persaingan lembaga PAUD tidak memperhatikan prinsip pembelajaran PAUD. Sehingga proses kegiatan belajar hanya sekedar rutinitas.

\section{KESIMPULAN DAN SARAN}

Perkembangan pendidikan anak usia dini berkembang dengan pesat. Hal tersebut tentunya tidak lepas dari konteks pembelajaran yang dilakukan di lembaga PAUD. Konteks pembelajaran dipengaruhi oleh berbagai factor, (1)sarana prasarana,(2) tenaga pendidik, sekolah, (3) tenaga kependidikan, dan factor psikologis lainnya. Tujuan dari penelitian ini adalah untuk mengetahui factor-faktor yang mempengaruhi pembelajaran guru PAUD Jabodetabek.

Penelitian ini bersifat deskriptif analitik, yaitu data dideskripsikan dengan menggunakan statistik deskriptif, dan dimaknai secara mendalam berdasarkan perspektif emik yaitu penyajian data secara alamiah tanpa melakukan suatu manipulasi atau perlakuan terhadap subjek yang diteliti serta diperkuat melalui triangulasi data melalui observasi dan wawancara pengurus dan pendidik PAUD, orang tua, dan masyarakat sekitar sekolah. 
Terdapat 21 lembaga PAUD dalam penelitian ini. Berdasarkan hasil penelitian dapat disimpulkan : pertama, terdapat $85 \%$ pembelajaran dilakukan dengan konteks pembelajaran klasikal, kedua, terdapat beberapa factor yang mempengaruhi pembelajaran guru PAUD, yaitu: (1) luas lahan yang tidak memenuhi standar (2) kompetensi pendidik yang kurang mengeksplore potensi anak didik (3) biaya pendidikan yang bersaing dengan lembaga PAUD lainnya dan (4) sarana prasarana yang sangat minim.

\section{DAFTAR PUSTAKA}

[1] Arce, Eve-Marie, Curriculum for Young Children: An Introduction (New York: Delmar Thomson Learning, 2000)

[2] Barrel, John Teaching for Thoughfullness: Classroom Strategies to Enhance Intelectual Development Second Edition, New York: Longman Group Ltd., 1995.

[3] Bredekamp, Sue dan Teresa Rosegrant, "Reaching Potentials: Introduction" Reaching Potentials: Appropriate Curriculum and Assessment for Young Children Volume 1 Editor Sue Bredekamp and Teresa Rosegrant, Washington: NAEYC, 1999.

[4] Bredekamp, Sue and Teresa Rosegrant, "Reaching Potentials Through Appropriate Curriculum Conceptual Frameworks for Applying the Guidelines" Reaching Potentials: Appropriate Curriculum and Assessment for Young Children Volume 1 Editor Sue Bredekamp and Teresa Rosegrant, Washington: NAEYC, 1999.

[5] Brewer, Jo Ann, Introduction to Early Childhood Education: Preschoolthrough Primary Grades Sixth Edition, New York: Pearson, 2007.

[6] Burchfield, David W., dan Bonnie C. Burchfield, "Two Primary Teachers Learn and Discover Through a Process of Change" Reaching Potentials: Appropriate Curriculum and Assessment for Young Children Volume 1 Editor Sue Bredekamp and Teresa Rosegrant, Washington: NAEYC, 1999.

[7] Drake, Susan M., Creating Standards_based Integrated Curriculum: Alighning Curriculum, Content,
Assessment and Instruction, Second Edition, California: Corwin Press A Sage Publication Company, 2007.

[8] Essa, Eva L. Introduction to Early Chilhood Education: Annotated Student's Edition (Nevada: Thomson Delmar Learning, 2003)

[9] Espinosa, Linda, "The Process of Change: The Redwood City Story" Reaching Potentials: Appropriate Curriculum and Assessment for Young Children Volume 1 Editor Sue Bredekamp and Teresa Rosegrant, Washington: NAEYC, 1999.

[10] Feeney, Stephanie. Who Am I in The lives of Children? Seventh Edition New Jersey: Pearson Merrill Prentice Hall, 2006.

[11] Fogarty, Robin, The Mindful School How To Integrate The Curricula, Illinois: IRI SkyLight Training and Publishing, Inc., 1991.

[12] Gestwicki, Carol Developmentally Appropriate Practice: Curriculum and Development in Early Education Third Edition, Canada:Thomson Delmar Learning, 2007.

[13] Isbell, Rebbeca, The Complete Learning Center Book: An Illustrated Guide for 32 Different Early Childhood Learning Centers, Maryland: Gryphon House, 1995.

[14] Ministry of Education Singapore, Framework Book 1 Kindergarten Curriculum Singapore: Nurturing Early Learners, 2003.

[15] Pica, Rae, Moving and Learning Across The Curriculum: More tha 300 Games Activities to Make Learning Fun, Canada: Thomson Delmar Learning, 2007.

[16] Schickendanz, Judith A, et all., Understanding Children and Adolescents Fourth Edition Boston: Allyn and Bacon, 2001.

[17] Schickendanz, Judith A. Increasing the Power of Instruction: Integration of Language, Literacy and Math across the Presschool Day, Washington: NAEYC, 2008.

[18] Wolfgang, Charles H., Mary E. Wolfgang, School for Young Children: Developmentally Appropriate Practice, Boston, 1992. 
[19] Yussen, Steven R., John W. Santrock, Child Developmet: An Introduction Iowa: WCB, 1980)

[20] Zais, Robert S., Curriculum: Principles and Foundations New York: Harper and Row Publisher, 1976. 